\title{
RESPON NILAI KEKERASAN, KADAR AIR DAN TOTAL PADATAN TERLARUT BUAH JAMBU KRISTAL PADA BERBAGAI JENIS KEMASAN DAN MASA SIMPAN
}

\section{Response Hardness Values, Water Content and Total Soluble Solids of Crystal Guava Fruit in Different Types of Packaging and Storage Period}

\author{
Kusumiyati, Ine Elisa Putri, Yuda Hadiwijaya, Syariful Mubarok \\ Program Studi Agroteknologi Fakultas Pertanian Universitas Padjadjaran \\ Jl. Raya Bandung Sumedang KM.21, Sumedang 45363 \\ Korespodensi: kusumiyati@unpad.ac.id
}

Diterima 07 Februari 2019 / Disetujui 21 Juni 2019

\begin{abstract}
ABSTRAK
Penurunan kualitas selama penyimpanan merupakan permasalahan yang sering ditemukan pada pascapanen buah jambu kristal. Oleh karena itu, diperlukan penanganan yang tepat. Penanganan pascapanen yang umum digunakan adalah penggunaan kemasan. Tujuan penelitian ini adalah untuk mengkaji hubungan berbagai kemasan dan masa simpan terhadap nilai kekerasan, kadar air, dan total padatan terlarut (TPT) buah jambu kristal. Penelitian ini menggunakan Rancangan Acak Lengkap (RAL) pola faktorial dengan 4 ulangan. Faktor pertama adalah pengemasan (tanpa kemasan (kontrol), plastik wrapping, koran) dan faktor kedua adalah masa simpan (0, 4, 8 hari). Data yang diperoleh diolah dengan analisis sidik ragam (ANOVA), selanjutnya diuji Duncan dengan taraf $5 \%$. Hasil yang didapatkan menunjukkan tidak terjadi interaksi antara jenis kemasan dan masa simpan terhadap nilai kekerasan, kadar air, dan TPT buah jambu kristal. Namun, jenis kemasan koran menunjukkan nilai kekerasan buah jambu kristal yang lebih rendah dibandingkan dengan perlakuan tanpa kemasan (kontrol) dan plastik wrapping, sedangkan masa simpan 0 hari memperlihatkan nilai kekerasan buah jambu kristal yang lebih tinggi dibandingkan dengan masa simpan 4 dan 8 hari. Nilai kekerasan buah mengalami penurunan setelah 4 hari penyimpanan. Penggunaan kemasan berupa plastik wrapping dan koran tidak lebih baik dibandingkan dengan tanpa pengemasan (kontrol) terhadap nilai kekerasan pada buah jambu kristal.
\end{abstract}

Kata kunci: kadar air, nilai kekerasan, Psidium guajava L, total padatan terlarut

\section{ABSTRACT}

Losses during storage is often encountered in the postharvest of crystal guava fruit. Therefore, proper handling is needed. Packaging is the most commonly performed in postharvest handling. The purpose of this study was to examine the relationship of various packaging and storage period to the hardness value, water content, and total soluble solids of crystal guava fruit. This study used factorial completely randomized block design (CRBD) with four replications. The first factor was packaging (without packaging (control), wrapping plastic, paper), and the second factor was storage period $\left(0,4,8\right.$ days) in a room temperature $\left( \pm 25^{\circ} \mathrm{C}\right)$. The data obtained was processed using analysis of variance (ANOVA), and the Duncan test was carried out in a level of $5 \%$. The results showed no interaction between the types of packaging and storage periods to the values of hardness, TSS, and water content of crystal

Cite this as: Kusumiyati. Putri, I. E. Hadiwijaya, Y \& Mubarok, S.(2019). Respon nilai kekerasan, kadar air dan total padatan terlarut buah jambu kristal pada berbagai jenis kemasan dan masa simpan. Jurnal Agro, 6(1), 49-56 https://doi.org/10.15575/4142 
guava fruit. However, the paper packaging presented the hardness value was lower than without packaging (control) and wrapping plastic, whereas the 0 day storage showed the hardness value fruit was higher than the 4 and 8 days storage. Value of fruit hardness decreased after 4 days of storage. Without packaging (control) was better than using of wrapping plastic and paper to the hardness value of the crystal guava fruit.

Key words: hardness, Psidium guajava L, total soluble solids, water content

\section{PENDAHULUAN}

Buah jambu (Psidium guajava L.) memiliki berbagai macam kultivar. Jambu kristal adalah salah satu jenis kultivar yang dapat tumbuh di Indonesia. Buah ini merupakan hasil dari mutasi jambu Muangthai Pak dan dapat dibudidayakan di Sumedang. Karakteristik buah ini menjadi daya tarik konsumen. Buah jambu kristal berbentuk bulat, memiliki bobot berkisar antara 300 - 500 g per buah, rasanya manis, daging buah tebal, berwarna putih, bertekstur renyah dan memiliki sedikit biji.

Kualitas buah menjadi hal yang penting untuk diperhatikan. Produk buah harus dalam keadaan tetap segar saat diterima oleh konsumen. Buah yang segar dapat dimanfaatkan sebagai asupan nutrisi untuk menjaga kesehatan tubuh. Oleh karena itu, minat konsumen untuk mengonsumsi buah-buahan semakin bertambah seiring dengan kesadaran konsumen dalam menjaga kesehatan tubuh sehingg permintaan produk hortikultura bertambah (Putri et al., 2017).

Terdapat beberapa parameter kualitas buah yang dapat menjadi indikator kematangan buah. Ciri kematangan buah diindikasikan dari tingkat kekerasan buah, kadar air dan total padatan terlarut (TPT). Kekerasan adalah parameter kualitas buah yang dapat digunakan sebagai penentu masa simpan. Buah jambu kristal akan mengalami penurunan kekerasan selama penyimpanan (Chawla et al., 2018).
Kekerasan buah yang menurun tersebut merupakan salah satu efek dari respirasi buah. Selain itu, kadar air buah juga perlu diketahui untuk menggambarkan banyaknya kandungan air dan tingkat kerenyahan buah saat dikonsumsi. TPT meliputi gula reduksi, pektin, gula nonreduksi, asam-asam organik dan protein. Nilai TPT yang mengindikasikan total gula secara kasar dan sangat menentukkan kualitas pada buah-buahan. Namun kandungan gula pada buah-buahan memiliki jumlah yang tergolong banyak sehingga TPT dapat digunakan sebagai penafsiran rasa manis.

Masa simpan buah berkaitan dengan lamanya ketahanan buah. Buah yang semakin lama disimpan akan menunjukkan kemunduran kualitas, namun kemunduran kualitas dapat diperlambat dengan teknologi penanganan pascapanen. Kehilangan kualitas buah setelah panen masih cukup besar sehingga penanganan pascapanen yang tepat akan mengurangi kerusakan dan memperpanjang masa simpan buah.

Pengemasan merupakan salah satu penanganan pascapanen yang telah umum dilakukan oleh para produsen buahbuahan. Kemasan dengan plastik wrapping dan koran dapat digunakan sebagai bahan pembungkus buah. Produk buah-buahan pada umumnya menggunakan kemasan berupa koran dan plastik wrapping. Walaupun demikian, penggunaan kemasan tidak akan menghentikkan proses respirasi 
pada buah segar (Kalsum et al., 2017; Nayik \& Muzaffar, 2014).

Penyimpanan buah jambu biji telah dilakukan pada periode yang berbedabeda. Pada buah jambu biji penyimpanan di suhu ruang tidak dapat terlalu lama. Sitorus et al. (2014) menyebutkan buah jambu merah yang disimpan pada 0, 2, 4, 6 dan 8 hari menunjukkan lamanya penyimpanan memengaruhi kekerasan buah, semakin panjang waktu penyimpanan akan menurunkan kekerasan buah.

Kemasan buah menggunakan plastik wrapping dan koran dimaksudkan untuk dapat memodifikasi udara yang berada di sekitar buah. Jumlah $\mathrm{O}_{2}$ yang berada di sekitar buah diharapkan dapat diminimalisir dengan penggunaan kemasan plastik wrapping dan koran. Selain itu, laju respirasi akan menurun dengan penggunaan kemasan yang tepat sehingga dapat memperlambat penurunan kualitas buah. Pada saat dilakukan penyimpanan buah dalam kemasan akan bertahan lebih lama dengan respirasi yang rendah. Buah yang dikemas diharapkan akan memiliki masa simpan produk lebih lama dengan perlakuan pengemasan. Perlakuan pengemasan selama dilakukan proses penyimpanan akan memperlambat laju kemunduran kualitas buah (Herawati, 2008).

Berdasarkan uraian diatas diharapkan akan terjadi interaksi antara jenis kemasan dan masa simpan. Tujuan dari penelitian ini adalah untuk mengkaji hubungan berbagai kemasan dan masa simpan terhadap nilai kekerasan, kadar air dan TPT buah jambu kristal. Penggunaan jenis kemasan dan masa simpan diharapkan dapat memberikan manfaat berupa informasi kepada masyarakat secara luas, khususnya para pelaku industri ataupun peneliti.

\section{BAHAN DAN METODE}

Penelitian dilakukan di Laboratorium Hortikultura Fakultas Pertanian, Universitas Padjadjaran, Jatinangor. Penelitian ini berlangsung dari mulai Maret hingga Juli 2018. Sampel yang digunakan adalah buah jambu kristal (Psidium guajava L.). Buah jambu kristal berasal dari Desa Karyamukti, Kecamatan Tomo, Kabupaten Sumedang dan dipanen 45 hari setelah bunga mekar.

Sampel buah jambu kristal diberikan perlakuan yang terdiri dari 2 faktor, yaitu: Faktor 1 adalah jenis kemasan (A):

$\mathrm{A}_{0}$ : tanpa kemasan (kontrol)

$\mathrm{A}_{1}$ : plastik wrapping

$A_{2}$ : koran

Faktor 2 adalah masa simpan (B):

$\mathrm{B}_{0}: 0$ hari

$\mathrm{B}_{1}: 4$ hari

$\mathrm{B}_{2}: 8$ hari

Kombinasi perlakuan berjumlah 9 dengan 4 ulangan. Tiap unit ulangan menggunakan 4 sampel sehingga total tedapat 144 sampel buah. Rancangan yang digunakan pada penelitian ini yaitu metode eksperimen Rancangan Acak Lengkap (RAL) pola faktorial. Data yang didapatkan diolah dengan analisis sidik ragam (ANOVA) menggunakan SPSS 21, selanjutnya diuji Duncan dengan taraf $5 \%$.

Pengujian diawali dengan menguji nilai kekerasan buah, lalu mengecek nilai TPT dan selanjutnya menguji nilai kadar air buah. Kekerasan buah diuji dengan menggunakan alat tension gauge (AND Model AD-4932A50 N, Taiwan). Pengambilan sampel dilakukan dengan cara menusukkan alat pada bagian tengah buah hingga muncul angka dalam satuan Newton (Weliana et al., 2014). Pengukuran 
nilai TPT dilakukan dengan cara memarut buah terlebih dahulu hingga diperoleh cairannya lalu diteteskan pada alat pengukur refraktometer (PR1 Atago, Japan) (Nasution et al., 2012). Alat tersebut dinyatakan dalam satuan \%Brix. Kadar air buah diukur dengan cara gravimetri dengan menggunakan oven pada suhu $80^{\circ} \mathrm{C}$ hingga buah yang dikeringkan tersebut konstan (AOAC, 1995). Nilai TPT dan kadar air didapatkan dari rerata bagian atas (dekat tangkai buah), tengah dan bawah buah.

\section{HASIL DAN PEMBAHASAN}

Kekerasan buah adalah indikator kematangan buah yang paling mudah dilakukan oleh konsumen. Pada buah jambu kristal biasanya buah yang telah siap dikonsumsi tidak keras dan mudah digigit. Konsumen seringkali mengukur kekerasan buah dengan meraba atau menekan buah secara langsung. Pada saat dipanen buah jambu kristal relatif agak keras, namun akan berubah lebih lunak setelah dilakukan penyimpanan.

Kombinasi kemasan dan masa simpan tidak menunjukkan interaksi pada kekerasan buah. Tetapi, terdapat faktor mandiri dari kemasan dan masa simpan yang berbeda nyata (Tabel 1). Buah jambu kristal pada berbagai kemasan menghasilkan nilai kekerasan yang beragam. Nilai kekerasan buah jambu kristal tanpa kemasan yaitu 23,75 N, plastik wrapping sebesar 23,24 $\mathrm{N}$ dan koran yaitu $17,44 \mathrm{~N}$ sedangkan kekerasan buah jambu kristal yang disimpan 0 hari yaitu $24,75 \mathrm{~N}$, disimpan 4 hari yaitu 20,38 $\mathrm{N}$ dan disimpan 8 hari sebesar 19,30N. Yulianti dkk. (2016) melaporkan bahwa buah jambu kristal yang telah disimpan 0,2 dan 4 hari dan diberi perlakuan air panas menyebabkan kekerasannya menurun berkisar antara \pm 43
$\mathrm{N}$ hingga menjadi $\pm 13 \mathrm{~N}$ dalam suhu ruang $\pm 28^{\circ}$.

Tabel 1. Pengaruh berbagai jenis kemasan dan masa simpan terhadap kekerasan buah jambu kristal

\begin{tabular}{lc}
\hline Perlakuan & $\begin{array}{c}\text { Kekerasan } \\
\text { (Newton) }\end{array}$ \\
\hline Tanpa kemasan & $23,75 \mathrm{~b}$ \\
Plastik wrapping & $23,24 \mathrm{~b}$ \\
Koran & $17,44 \mathrm{a}$ \\
\hline Simpan 0 hari & $24,75 \mathrm{~b}$ \\
Simpan 4 hari & $20,38 \mathrm{a}$ \\
Simpan 8 hari & $19,30 \mathrm{a}$ \\
\hline
\end{tabular}

Keterangan : Nilai rerata yang dilambangkan dengan huruf yang sama pada kolom yang sama menunjukkan tidak berbeda nyata menurut uji Duncan bertaraf 5\%.

Pengemasan koran lebih lunak dan berbeda nyata dibandingkan dengan tanpa kemasan dan plastik wrapping, hal ini dikarenakan koran akan menyerap uap air yang dihasilkan dari respirasi buah, lingkungan buah menjadi lembab dan mempercepat buah melakukan metabolisme sehingga buah menjadi lebih lunak. Faktor masa simpan menunjukkan masa simpan 0 hari lebih keras dan berbeda nyata dengan masa simpan 4 dan 8 hari.

Perlakuan tanpa kemasan dan plastik wrapping tidak berbeda nyata, hal ini sejalan dengan penelitian Kalsum et al. (2017) bahwa buah jambu merah tanpa kemasan dan plastik wrapping tidak berbeda nyata pada parameter kekerasan buah. Udara lembab disekitar buah yang dikemas dengan koran mengindikasikan bahwa sirkulasi udara kemasan koran kurang baik jika dibandingkan plastik wrapping dan tanpa kemasan, karena selama penyimpanan udara sekitar buah menjadi lembab dan menyebabkan uap air hasil respirasi terserap oleh koran dan semakin lama koran menjadi lebih basah. 
Kualitas buah-buah setelah dilakukan pemanenan akan berkaitan dengan sirkulasi udara dan bahan pembentuk kemasan (Saeed et al., 2010).

Kekerasan buah mengalami penurunan apabila semakin lama disimpan. Penelitian Kusumiyati et al. (2017) membuktikan bahwa kekerasan buah sawo yang disimpan 0, 5 dan 10 hari terus mengalami penurunan dengan semakin lama dilakukan penyimpanan. Terjadi perombakan zat yang terdapat didalam buah-buah tersebut selama penyimpanan. Penurunan nilai kekerasan buah terjadi karena protopektin yang tidak larut terombak menjadi pektin dan asam pektat yang dapat larut didalam air (Fransiska et al., 2013).

Perlakuan jenis kemasan dan masa simpan tidak menunjukkan interaksi untuk kadar air buah jambu kristal. Faktor mandiri dari masing-masing perlakuan tidak memengaruhi nilai kadar air dari buah jambu kristal (Tabel 2). Penelitian Murtiningrum et al. (2013) menyatakan bahwa kadar air buah drupa merah tidak menghasilkan perbedaan yang nyata pada berbagai kemasan plastik di suhu ruang.

Tabel 2. Pengaruh berbagai jenis kemasan dan masa simpan terhadap kadar air buah jambu kristal

\begin{tabular}{lc}
\hline Perlakuan & Kadar air (\%) \\
\hline Tanpa kemasan & $89,39 \mathrm{a}$ \\
Plastik wrapping & $87,27 \mathrm{a}$ \\
Koran & $87,56 \mathrm{a}$ \\
\hline Masa simpan 0 hari & $87,20 \mathrm{a}$ \\
Masa simpan 4 hari & $86,13 \mathrm{a}$ \\
Masa simpan 8 hari & $90,88 \mathrm{a}$ \\
\hline Keterangan : Nilai rerata yang dilambangkan \\
dengan huruf yang sama pada kolom yang \\
sama menunjukkan tidak berbeda nyata \\
menurut uji Duncan bertaraf 5\%.
\end{tabular}

Kadar air buah jambu kristal menyiratkan kenaikan kadar air pada hari ke-8 penyimpanan, walaupun secara uji statistik tidak berbeda nyata. Hal ini terjadi karena buah semakin matang. Kadar air buah akan semakin tinggi bersamaan dengan level kematangannya yang bertambah, tetapi nilai kekerasan buah akan mengindikasikan penurunan (Julianti, 2011).

Hasil analisis sidik ragam pada parameter TPT menunjukkan tidak ada interaksi antar faktor kemasan dan masa simpan. Jenis kemasan dan masa simpan tidak memengaruhi nilai \%Brix pada buah jambu kristal, hal ini ditunjukkan dengan nilai \%Brix tidak berbeda nyata pada berbagai taraf. Nilai \%Brix yang tidak berbeda nyata mengindikasikan bahwa perlakuan berbagai jenis kemasan dan masa simpan tidak memengaruhi TPT. Nilai TPT buah kristal tanpa kemasan yaitu 9,44 $\%$ Brix, pada plastik wrapping sebesar 7,84 \%Brix, dan pada koran yaitu 8,15 \%Brix (Tabel 3).

Tabel 3. Pengaruh berbagai jenis kemasan dan masa simpan terhadap TPT buah jambu kristal

\begin{tabular}{lc}
\hline Perlakuan & TPT (\%Brix) \\
\hline Tanpa kemasan & $9,44 \mathrm{a}$ \\
Plastik wrapping & $7,84 \mathrm{a}$ \\
Koran & $8,15 \mathrm{a}$ \\
\hline Masa simpan 0 hari & $7,88 \mathrm{a}$ \\
Masa simpan 4 hari & $8,18 \mathrm{a}$ \\
Masa simpan 8 hari & $9,36 \mathrm{a}$ \\
\hline Keterangan: Nilai rerata yang dilambangkan \\
dengan huruf yang sama pada kolom yang \\
sama menunjukkan tidak berbeda nyata \\
menurut uji Duncan bertaraf 5\%.
\end{tabular}

Buah jambu kristal pada penyimpanan 0 hari yaitu 7,88\% Brix, penyimpanan 4 hari sebesar 8,18\% Brix dan penyimpanan 8 hari yaitu 9,36\% Brix. Nilai TPT buah jambu kristal berada pada kisaran 6,80 \% Brix hingga 12,87 \% Brix (Widodo et al., 2016; 
Romalasari et al., 2017). Masa simpan 0 hingga 8 hari memperlihatkan kenaikan nilai TPT walaupun tidak berbeda secara nyata. Nilai TPT yang tidak berbeda nyata dikarenakan buah ini tergolong buah nonklimaterik.

Kecepatan perubahan kualitas buah selama penyimpanan cukup beragam. Buah yang termasuk klimaterik dan nonklimaterik dibedakan berdasarkan laju respirasi. Buah yang termasuk kedalam buah klimaterik memiliki laju respirasi yang lebih tinggi dan signifikan apabila dibandingkan non-klimaterik setelah dilakukan pemanenan. Hasil penelitian dari berbagai parameter yang diujikan berupa kekerasan, TPT dan kadar air buah menunjukkan bahwa buah jambu kristal merupakan buah yang tergolong kedalam buah non klimaterik. Azzolini et al. (2005) menyatakan bahwa buah jambu kristal memiliki pola respirasi yang stabil dan tidak menunjukkan terdapatnya puncak klimaterik atau meningkatnya kecepatan produksi $\mathrm{CO}_{2}$ secara signifikan sehingga buah jambu kristal digolongkan kedalam buah non klimaterik. Berdasarkan penelitian ini dapat disimpulkan bahwa jenis kemasan dan masa simpan tidak menunjukkan interaksi terhadap kekerasan, TPT dan kadar air buah jambu kristal. Namun, terdapat faktor mandiri dari pelakuan jenis kemasan dan masa simpan menunjukkan hasil yang berbeda nyata pada parameter pengamatan kekerasan buah jambu kristal.

\section{SIMPULAN}

1. Kombinasi jenis kemasan dan masa simpan tidak menunjukkan interaksi terhadap nilai kekerasan, total padatan terlarut (TPT), dan kadar air buah jambu kristal.
2. Jenis kemasan koran menunjukkan nilai kekerasan buah jambu kristal yang lebih rendah daripada perlakuan tanpa kemasan (kontrol) dan plastik wrapping, sedangkan masa simpan 0 hari memperlihatkan nilai kekerasan buah jambu kristal yang lebih tinggi dibandingkan dengan masa simpan 4 dan 8 hari.

\section{UCAPAN TERIMAKASIH}

Peneliti mengucapkan terimakasih kepada Universitas Padjadjaran dan DRPMI UNPAD untuk bantuan dana penelitian.

\section{DAFTAR PUSTAKA}

AOAC. (1995). Official Methods of Analysis Association of Official of Analysis Chemist. Washington D.C.

Azzolini, M., Jacomino, A. P., Bron, I. U., Kluge, R. A., \& Schiavinato, M. A. (2005). Ripening of "Pedro Sato" Guava: Study on Its Climacteric or Non-climacteric Nature. Brazilian Journal of Plant Physiology, 17(3), 299-306. https://doi.org/ 10.1590/ S1677-04202005000300004

Chawla, S., Devi, R., \& Jain, V. (2018). Changes in Physicochemical Characteristics of Guava Fruits Due To Chitosan and Calcium Chloride Treatments During Storage. Journal of Pharmacognosy and Phytochemistry, 7(3), 1035-1044.

Fransiska, A., Hartanto, R., Lanya, B., \& Tamrin. (2013). Karakteristik Fisiologi Manggis (Garcinia mangostana L.) Dalam Penyimpanan Atmosfer Termodifikasi. Jurnal Teknik Pertanian, 2(1), 1-6.

Herawati, H. (2008). Penentuan Umur Simpan Pada Produk Pangan. Jurnal 
Litbang Pertanian, 27(4), 124-130.

Julianti, E. (2011). Pengaruh Tingkat Kematangan dan Suhu Penyimpanan Terhadap Mutu Buah Terong Belanda (Cyphomandra betacea). Jurnal Hortikultura Indonesia, 2(1), 14-20. https://doi.org/10.29244/jhi.2.1.1420

Kalsum, U., Sukma, D., \& Susanto, S. (2017). Pengaruh Bahan Kemasan terhadap Kualitas dan Daya Simpan Buah Jambu Biji Merah (Psidium guajava L.). Jurnal Pertanian Presisi, 1(1): 17-27.

Kusumiyati., Mubarok, S., Sutari, W., Farida., Hadiwijaya, Y., \& Putri, I. E. (2017). Kualitas Sawo (Achras zapota L .) Kultivar Sukatali Selama Penyimpanan. Jurnal Agrikultura, 28(2), 90-94.

Murtiningrum., Roreng, M. K., Sarungallo, Z. L., Jading, A., \& Watofa, M. (2013). Pengaruh Perbedaan Jenis Kemasan Plastik Pada Beberapa Suhu Penyimpanan Terhadap Umur Simpan Drupa Buah Merah (Pandanus conoideus L.) dan Kualitas Minyaknya. Dalam: Prosiding Seminar Nasional Perhimpunan Ahli Pangan Indonesia (PATPI), 26-29 Agustus 2013 di Jember, Jawa Timur, Indonesia. Bidang Rekayasa dan Bioteknologi Pangan, bagian 1: 287-295.

Nasution, I. S., Yusmanizar., \& Melianda, K. (2012). Pengaruh Penggunaan Lapisan Edibel (Edible Coating), Kalsium Klorida, dan Kemasan Plastik Terhadap Mutu Nanas (Ananas comosus Merr.) Terolah Minimal. Jurnal Teknologi dan Industri Pertanian Indonesia, 4(2), 21-26. https://doi.org/10.17969/jtipi.v4i2.26 8

Nayik, G. A., \& Muzaffar, K. (2014).
Developments In Packaging of Fresh Fruits-Shelf Life Perspective: A Review. American Journal of Food Science and Nutrition Research. 1(5): 34-39.

Putri, I. E., Suradinata, Y. R., \& Kusumiyati. (2017). Pengaruh Pemberian Berbagai Konsentrasi Benzyl Amino Purine (BAP) Terhadap Pertumbuhan Tiga Kultivar Tanaman Kamboja Jepang (Adenium arabicum). Jurnal Kultivasi, 16(1): 305-312.

Romalasari, A., Susanto, S., Melati, M., \& Junaedi, A. (2017). Perbaikan Kualitas Buah Jambu Biji ( Psidium guajava L .) Kultivar Kristal dengan Berbagai Warna dan Bahan Pemberongsong. 8(3), 155-161.

Saeed, F. A., Khan, N. S., Sarwar, A., \& Tahira, J. J. (2010). Effect of Packing Materials on Storage of Tomato. Mycopath, 8(2), 85-89.

Sitorus, R. F., Karo-karo, T., \& Lubis, Z. (2014). Pengaruh Konsentrasi Kitosan Sebagai Edible Coating dan Lama Penyimpanan Terhadap Mutu Buah Jambu Biji Merah. Jurnal Rekayasa Pangan Dan Pertanian, 2(1), 37-46.

Weliana, S., Sari, E. R., \& Wahyudi, J. (2014). Penggunaan $\mathrm{CaCO}_{3}$ untuk Mempertahankan Kualitas Tekstur dan Sifat Organoleptik Pisang Ambon (Musa acuminata) Selama Penyimpanan. Agritepa, I(1), 52-62.

Widodo, S. E., Kamal, M., \& Aprianti, D. (2016). Pengaruh 1Methylcyclopropene (1-MCP), Kitosan, dan Suhu Simpan Terhadap Masa Simpan Dan Mutu Jambu Biji (Psidium guajava L.) 'CRYSTAL.' 4(1), 29-35.

Yulianti, L. E., Hasbullah, R., \& Purwanti, N. (2016). Pengaruh Perlakuan Air Panas terhadap Mutu Buah Jambu Biji (Psidium guajava L.) Selama 
Penyimpanan. Jurnal Keteknikan

Pertanian, 4(2), 171-178.

https://doi.org/DOI:

10.19028/jtep.04.2.171-178 